Katarzyna Olbrycht*

Cieszyn

\title{
Jana Pawła II myślenie o związkach wiary i kultury - wyzwaniem dla wychowania chrześcijańskiego**
}

\begin{abstract}
Synteza kultury i wiary jest wymaganiem nie tylko kultury, lecz także wiary [...]. Wiara, która nie staje się kulturą, jest wiarą nie w pełni przyjęta, nie w całości przemyślaną, nie przeżytą wiernie ${ }^{1}$.
\end{abstract}

Problem związku wiary i kultury został zarysowany mocno w dokumentach Soboru Watykańskiego II i w nauczaniu kolejnych papieży. Potrzebę dostrzegania i realizowania tego związku szczególnie wyraźnie podkreślał Jan Paweł II. Jego słowa przywołane na wstępie pokazują, że kultura nie tyle i nie tylko jest owocem wiary, ale powinna nim być. Równocześnie jest i powinna być świadectwem wiary jako jej owoc.

Powierzchowna interpretacja wezwania do przekładania wiary na kulturę, wezwania powtarzanego przez Jana Pawła II na przestrzeni całego jego

* Prof. zw. dr hab. Katarzyna Olbrycht jest kierownikiem Zakładu Edukacji Kulturalnej w Wydziale Etnologii i Nauk o Edukacji Uniwersytetu Śląskiego w Cieszynie.

** Tekst we fragmentach wykorzystuje treści wykładu wygłoszonego w czasie Ogólnopolskiego Forum Szkół Katolickich w Częstochowie (listopad 2013).

1 Jan Paweł II, List do Kardynała Sekretarza Stanu Agostino Casaroli w zwiazku z powotaniem do życia Papieskiej Rady ds. kultury, Rzym, 20.05.1982, w: Wiara i kultura. Dokumenty, przemówienia, homilie, Rzym 1986, s. 161. 
pontyfikatu i kontynuowanego przez jego następców Benedykta XVI i Franciszka, może zrodzić pytanie: czy należy je rozumieć jako wezwanie kierowane do wszystkich? Nie każdy przecież ma związki ze światem kultury, nie każdy jest twórca, nie każdy ma warunki, żeby podejmować kontakty z kultura, szczególnie tą ambitniejsza, w tym - kontakty z kulturą jednoznacznie „chrześcijańską”, wreszcie nie każdy ma kompetencje do tego, żeby taką kulturę rozpoznać, wybrać wśród zalewających współczesnego człowieka ofert i marketingowych zachęt kultury masowej.

Gdyby kierować się przekazami społecznymi, medialnymi, sformułowaniami języka potocznego i komunikatami formalnymi, które odwołują się do „kultury”, zrozumienie tego pojęcia okazałoby się bardzo trudne. Pierwsze skojarzenie to najczęściej świat twórczości artystycznej, która od wieków stanowi „świat kultury”, skupia „ludzi kultury”, jest dziedziną, w której powstają „dzieła kultury”. To skojarzenie ma swoje mocne podstawy i nie jest przypadkiem, że to ono właśnie dominuje w myśleniu o kulturze, tym samym wywołując wspomniane wątpliwości co do tego, jak należy rozumieć związki kultury z wiarą, a przede wszystkim pytanie, czy dotyczą one każdego.

Dziś kragg znaczeń pojęcia kultury poszerza się w społecznej świadomości o takie określenia, jak: kultura społeczna, artystyczna, moralna, polityczna, pedagogiczna, kultura osobista i kultura bycia, a w kontekście odnoszenia kultury do miejsca lub czasu: kultura polska, europejska, regionalna, miejska, osiedlowa, kultura starożytna, średniowieczna, dawna i współczesna, itp. W obiegu językowym pojęcie kultury okazuje się coraz wygodniejsze do nazywania doraźnej sytuacji i charakteryzowania określonych zachowań wyróżniających daną grupę czy środowisko: kultura korporacyjna, kultura biznesu, kultura picia, kultura korzystania z dróg, kibicowania, świętowania, odpoczywania itp. Najbardziej potoczne rozumienie ogranicza jednak „kulturę człowieka" do korzystania z różnych ofert instytucji kultury (kina, teatru, filharmonii), podejmowania różnych form aktywności tradycyjnie uważanej za kulturalną (czytanie książek, słuchanie muzyki, własna twórczość), wreszcie - znajomości ogólnych zasad zachowania w danym środowisku czy społeczeństwie (savoir vivre, dobre wychowanie).

Równocześnie rolę przypisywaną dziś kulturze w praktyce życia społecznego trudno uznać za szczególnie istotna. Sprowadza się ją najczęściej do artystyczno-estetycznego dodatku do codziennego życia, do swoistego luksusu, sfery pięknych, ale trudno dostępnych wrażeń, przedmiotu aspiracji, ale też nierzadko traktuje się ją jako środek służący poprawianiu własnego wizerunku czy pozycji społecznej. 
Rozumienie pojęcia kultury dodatkowo komplikuje fakt, iż obok opisywania sposobu życia człowieka i jego wytworów służy ono równocześnie do oceniania i wyrażania sądów wartościujących o poszczególnych osobach, grupach czy społecznościach. Mówimy, że ktoś jest „bez kultury”, inny zaś prezentuje „wysoką kulturę”, w danym społeczeństwie „,uderza brak kultury” politycznej, kultury dialogu, kultury osobistej czy po prostu - brak kultury. Wielość filozoficznych, antropologicznych, socjologicznych i psychologicznych koncepcji kultury nie ułatwia świadomego poruszania się w świecie kultury.

W sytuacji tak wyraźnego chaosu pojęciowego i myślowego, związanego z rozumieniem i odwoływaniem się do kultury, namysł nad relacją wiary (tu - głównie wiary chrześcijańskiej) i kultury, próba wyjaśnienia sensu ich związku, wreszcie formułowanie wniosków, dotyczących wychowawczych konsekwencji takiego spojrzenia na kulturę, wymagają bliższego przyjrzenia się problemowi kultury z perspektywy chrześcijańskiej.

Jan Paweł II posługiwał się często określeniem „kultura prawdziwa”, uznając ją za sferę rozwoju człowieka, w której zawierają się i budują wartości duchowe, stanowiące centrum człowieczeństwa, człowieczeństwa integralnego, pełnego, łączącego wymiar materialny z duchowym. To w „kulturze prawdziwej" widział owoc wiary, kształt życia, który wyraża i potwierdza wiarę człowieka.

\section{Jana Pawła II rozumienie pojęcia „kultury prawdziwej”}

Zrozumienie tego określenia wymaga przywołania dwu głównych tradycji myślenia o kulturze. W myśl obydwu kultura jest właściwym jedynie człowiekowi kształtem życia. W obydwu też specjalną rolę w nadawaniu życiu ludzkiego kształtu odgrywa z jednej strony kultura duchowa, najczęściej interpretowana jako nauka, sztuka, religia, język, z drugiej strony - moralność. Różnica obu tradycji wynika ze sposobu rozumienia, co oznacza kształt życia „właściwy człowiekowi” - z tego, jak rozumiany jest tu człowiek i właściwy kształt jego życia.

Pierwsza $\mathrm{z}$ tradycji zakorzeniona jest w źródłowym znaczeniu słowa „kultura”, dotyczącym „uprawy” (najpierw jedynie ziemi, później także ducha), i tu kultura jest procesem i efektem „uprawiania człowieczeństwa” zarówno w sensie pracy nad własnym człowieczeństwem, nad człowieczeństwem poszczególnych jednostek, jak i nad ludzkim wymiarem społeczeństwa. Człowiek w świetle tej tradycji jest jedyną istotą, która w trudzie do- 
skonalenia nadaje swojemu życiu, a poprzez więzi i stosunki międzyludzkie także życiu swojej społeczności, określony kształt, kształt „ludzki”. Jest więc twórcą kultury. Dzięki jego wysiłkom poziom „uczłowieczenia” i jego samego, i tych wśród których żyje, i wytworów służących tej pracy, a więc świata, w którym żyje, wzrasta. Realizacja tego procesu wymaga świadomej aktywności, trwającej przez całe życie pracy nad sobą i nad „uczłowieczaniem" świata. Jest to praca, która zmienia ten świat w miejsce coraz bardziej sprzyjające rozwojowi człowieka, rozwojowi rozumianemu osobowo - dążeniu do prawdy o człowieku i świecie, do dobra i piękna, spełnianiu siebie w miłości jako byciu darem, służeniu dobru wspólnemu, w kontemplowaniu i chwaleniu Boga, w podejmowaniu z radością swojego powołania.

Druga tradycja, osadzona w antropologii kulturowej, również przyjmuje, że kultura jest kształtem życia człowieka, obejmującym wartości, wzory i normy, jakimi człowiek się kieruje, zachowania i działania, jakie realizuje, oraz wytwory tych zachowań (ich treści i formy). Akcentuje jednakże, iż kultura jest kształtem życia właściwym dla danej grupy czy społeczności, to znaczy cechującym tę grupę, a więc będącym podstawą jej tożsamości, czynnikiem integrującym, pozwalającym zrozumieć jej historię i współczesność poprzez jej dorobek i racje działań podejmowanych przez jej członków. W tym ujęciu kultura, jako świat zachowań i wytworów człowieka, sposobów jego myślenia i działania, określa go, składa się na jego „wizerunek", wyjaśnia i uzasadnia jego sposób i styl życia. Wielość sposobów życia różnych grup prowadzi do wielości kultur, a społeczna świadomość wielości kultur i uznanie ich równoważności - do szukania możliwości porozumienia między nimi i budowania warunków dialogu.

Człowiek jest przez kulturę zewnętrzną kształtowany, ponieważ żyjąc zgodnie z przyjętymi normami, wzorami, wartościami, wzrastając w otoczeniu wytworzonym w procesie „uczłowieczania się” jego społeczności, wychowywany w rodzinie, pozostający pod wpływem oddziaływań różnych środowisk, przyjmuje określony sposób życia za swój. Staje się członkiem kultury swojej społeczności i czasu.

Te dwa ujęcia $\mathrm{w}$ istocie są komplementarne, dopełniają się i uzupełniają. Jednostronny wybór i powierzchowna interpretacja któregoś z nich może prowadzić do wykrzywienia obrazu kultury. Dziś mamy do czynienia z takim właśnie zagrożeniem, które potencjalnie może być źródłem nieporozumień, dylematów, a nawet konfliktów związanych z odwoływaniem się do argumentów dotyczących odmiennie rozumianej kultury. Obserwujemy, że zaczyna dominować myślenie o kulturze jako zbiorze zewnętrznych warunków nie tylko oddziałujących, ale determinujących życie człowieka. Stąd 
częste postawy pesymizmu, rezygnacji, bezradności i bierności wobec zatrważających diagnoz dotyczących kultury współczesnej.

Na problem ten zwrócił uwagę Jan Paweł II już w jednym z pierwszych wygłoszonych na forum międzynarodowym, i najważniejszych dla współczesnej kultury, przemówień w siedzibie UNESCO w Paryżu w 1980 roku. Podkreślał w nim, iż, oczywiście, można poznawać człowieka i jego kulturę poprzez świat jego wytworów, ale nie można zapominać, że „Człowiek, i tylko człowiek, jest sprawcą i twórcą kultury; człowiek i tylko człowiek w niej się wyraża i w niej się potwierdza"2. Nie wystarczy więc szukać prawdy o człowieku w jego kulturze, choć jest to ważna płaszczyzna jego poznania i zrozumienia. Trzeba zaczynać od pytania o istotę człowieka, jego człowieczeństwa. Jeśli kultura jest wyrazem pracy istot ludzkich nad własnym człowieczeństwem, podstawowym pytaniem domagającym się odpowiedzi jest: kim jest i kim ma być człowiek? Co ma w sobie doskonalić? Co jest istotą człowieczeństwa? Pytania te sprowadzają się do jednego: jaka jest prawda o człowieku? Czy da się ją poznać, nie szukając prawdy o świecie, o Bogu, o stosunku człowieka do siebie, do innych ludzi i do Boga?

Od początku swojego pontyfikatu Jan Paweł II uświadamiał światu, że kulturze współczesnej pilnie potrzebna jest właściwa, ,zdrowa” antropologia - uznanie w człowieku osoby - istoty, w której integralnie łączą się wymiar fizyczny, psychiczny i duchowy. Mówił:

Kultura jest tym, przez co człowiek jako człowiek staje się bardziej człowiekiem: bardziej ,jest”. Na tym także opiera się owo kapitalne rozróżnienie pomiędzy tym, czym człowiek jako człowiek jest, a tym, co posiada [...]. Wszystko, co człowiek „ma”, o tyle jest ważne dla kultury, o tyle jest kulturotwórcze, o ile człowiek przez to, co posiada, może równocześnie pełniej „,być” jako człowiek, pełniej stawać się człowiekiem we wszystkich właściwych człowieczeństwu wymiarach jego bytowania ${ }^{3}$.

Koncepcja ta jest oparta na uznaniu bezwarunkowej godności osoby ludzkiej, jej wolności i rozumności, na orientacji na wartości duchowe - prawdę, dobro i piękno, na dążeniu do transcendencji, na spełnianiu się w byciu bezinteresownym darem dla drugiego, w konstruktywnym dążeniu do

2 Tenże, Przemówienie w siedzibie UNESCO, Paryż, 2.06.1980, w: Przemówienia i homilie Ojca Świętego Jana Pawła II, Kraków 2008, s. 283.

3 Tenże, Przemówienie na Uniwersytecie Narodów Zjednoczonych w Hiroszimie, 25.02.1981, w: Przemówienia, s. 310. 
realizowania dobra wspólnego (rozumianego osobowo) we wspólnotach. Człowiek widziany osobowo, rozumiejący, że jest osoba, szanowany jako osoba, a także społeczeństwo respektujące w swoich członkach ich osobowy status, budują kształt życia społecznego tak, by każdy mógł bardziej „być” niż „mieć”. W ten sposób tworzona jest „,prawdziwa” kultura. Równocześnie tylko kultura prawdziwa może sprzyjać rozwojowi osobowemu jednostek i społeczeństw.

Z perspektywy Kościoła „prawdziwa” kultura pozwala zarówno nieść ewangelię do innych kultur, z pełnym szacunkiem dla ich przedstawicieli i ich dorobku, z gotowością odkrywania, jak rozwijali i rozwijają swoje człowieczeństwo w konkretnych warunkach i przestrzeni, jak i niezależnie od kulturowych uwarunkowań ochraniać każdego człowieka w jego godności, zachęcać go i wspomagać w podejmowanych wysiłkach osobowego rozwoju4 .

„Prawdziwa” kultura jest więc kształtem życia zorientowanego na prawdę, życia dążącego do kształtowania człowieczeństwa - własnego i innych zgodnie z prawdą o człowieku i świecie. Nawet jeśli w nauczaniu Kościoła i wypowiedziach ludzi Kościoła dotyczących kultury nie pojawia się określenie „kultura prawdziwa” w znaczeniu wprowadzonym przez Jana Pawła II, to w świetle chrześcijańskiego widzenia człowieka i jego kultury treści związane z kulturą najczęściej dotyczą właśnie kultury prawdziwej.

Sens kultury jako kultury prawdziwej Jan Paweł II wyjaśniał w wielu miejscach, przybliżając jej pozytywne (tzn. czym jest) i negatywne (jaką kulturą nie jest) rozumienie. Przytoczmy kilka znaczących interpretacji. W Pradze do ludzi nauki i kultury Ojciec Święty mówił:

Bez perspektywy transcendentnej, bez zmysłu przekraczania widzialnej rzeczywistości każda kultura pozostaje żałosnym fragmentem, niczym wieża Babel. Nie można budować kultury, pomijając czy uparcie odrzucając to, czym jest cultus - szacunek, poszanowanie. Człowiek niekulturalny i naród niekulturalny to człowiek i naród bez szacunku dla siebie, dla bliźniego, dla świata, dla Boga 5 .

4 Tenże, Przemówienie do członków Papieskiej Rady do spraw Kultury, Rzym, 18.01.1983, w: Przemówienia, s. 300.

5 Tenże, Przemówienie do ludzi nauki i kultury, Praga, 21.04.1990, w: Przemówienia, s. 334 . 
Po tak klarownej charakterystyce prawdziwej kultury, w pełni czytelne jest zawarte w następnym zdaniu stwierdzenie: „Życie pozbawione kultury [co można rozumieć - pozbawione kultury prawdziwej - K. O.] to życie bez głębi, bez tajemnicy, bez ducha, życie zdeterminowane jedynie użyciem i konsumpcją, życie płytkie". Z kolei w przemówieniu do Papieskiej Akademii Nauk Jan Paweł II przeciwstawił kulturę prawdziwą - kulturze „rozdartej”, zagrażającej współczesnemu światu i człowiekowi. Powiedział:

Współczesna kultura czyni koniecznym nieustanny wysiłek syntezy danych i integracji wiedzy. To prawda, że sukcesy nauki, których jesteśmy świadkami, są wynikiem specjalizacji poszukiwań. Jeśli jednak nie równoważy jej refleksja zmierzająca do ukazania wzajemnych powiązań różnych dziedzin wiedzy, powstaje ogromne ryzyko ukształtowania się „kultury rozdartej”, która byłaby $\mathrm{w}$ istocie zaprzeczeniem prawdziwej kultury. Kultura nie jest bowiem do pomyślenia bez humanizmu i mądrości ${ }^{6}$.

Kultura prawdziwa musi więc być kulturą pełną, opartą na mądrości i humanizmie. Zaznaczmy, że Jan Paweł II mówił o „nowym humanizmie” traktującym człowieka jako osobę obdarzoną bezwzględną wartością, istotę odkupioną przez Chrystusa i powołaną do świętości. Istotę, która może przekraczać siebie „dla trwałego wcielania w dzieła sztuki i myśli transcendentnych wartości piękna i prawdy”, w których „mniej lub bardziej przelotnie” wyczuwa wyraz absolutu8.

Przywoływane już przemówienie w siedzibie UNESCO w Paryżu zawiera sformułowania zasadnicze dla właściwego rozumienia „kultury prawdziwej”, to znaczy pełnej: „Nie ulega wątpliwości, że pierwszym i podstawowym zjawiskiem kulturowym jest sam człowiek, duchowo dojrzały, czyli człowiek w pełni wychowany, zdolny wychowywać sam siebie i drugich. Nie ulega też wątpliwości, że pierwszym i podstawowym wymiarem kultury jest zdrowa moralność: kultura moralna"".

Odwołując się do Jana Pawła II myślenia o kulturze, trzeba więc rozumieć kulturę jako świat człowieka, ale człowieka widzianego w prawdzie o nim i jego istocie, o jego celu i miejscu w świecie. Trzeba przyjać, że

${ }^{6}$ Tenże, Przemówienie do Papieskiej Akademii Nauk, Rzym, 31.10.1992, w: Przemówienia, s. 358.

7 Tenże, List do Kardynała, s. 162.

8 Tamże.

9 Tenże, Przemówienie $w$ siedzibie UNESCO, s. 288. 
„Prawdziwa kultura człowieka leży w głębi jego istoty”10. A jeśli ma być dziełem tworzonym przez człowieka i tworzącym go w całej jego integralności, musi być kulturą prawdziwą, kulturą pełną, „właściwym sposobem istnienia i bytowania człowieka" ${ }^{11}$. Jest to warunek tego, by kultura mogła służyć „wyniesieniu człowieka i rozwojowi współpracy między narodami”"12.

To, że jakiś fragment życia danej grupy jest z perspektywy kulturoznawczej na tyle dla niej charakterystyczny, że opisywany jest jako element jej kultury, że jakaś aktywność jest analizowana przez socjologów jako uczestniczenie w kulturze i powszechnie kojarzona z kultura, nie oznacza jeszcze, że z perspektywy chrześcijańskiej mamy do czynienia z kulturą prawdziwa, pełną, tą, która stanowi owoc wiary.

\section{Relacja wiary i kultury}

Tak jak potoczne rozumienie kultury stawia ją na luksusowym marginesie życia codziennego, tak powierzchowne traktowanie wiary zamyka ją w prywatnej sferze duchowych przeżyć człowieka, również nie wiążąc jej z kształtem codziennego życia i tworzących go sposobów myślenia, działania, dokonywania wyborów życiowych, podejmowania decyzji, sposobów funkcjonowania wśród ludzi, przeżywania radości i dramatów, wykonywania pracy i świętowania. I wiara i kultura pozbawione swego prawdziwego sensu w praktyce stanowią więc marginesy „normalnego” życia, dodawane do niego, ale nie wpływające znacząco na jego kształt. W tym świetle nie dziwi sytuacja, w której kultura współczesna jako kształt życia współczesnych społeczeństw w niewielkim stopniu wyraża wiarę jednostek i społeczności w Boga, częściej wydaje się świadczyć o braku głębszego ich związku z wiarą. Samą kulturę chrześcijańską interpretuje się raczej jako kulturę sięgającą do tematyki chrześcijańskiej, niż wyrastającą z chrześcijańskiej wiary kulturę, będącą wyrazem i potwierdzeniem wiary jej twórców. A twórcami kultury są przecież nie tylko twórcy dzieł kultury duchowej - sztuki i nauki, ale wszyscy, którzy budują swoje życie, nadając mu kształt bardziej lub mniej zgodny ze swoją wiarą.

10 Tenże, Przemówienie na Uniwersytecie, s. 310.

11 Tenże, Przemówienie $w$ siedzibie UNESCO, s. 282.

12 Tenże, Przemówienie do intelektualistów, Combra, 15.05.1982, w: tenże, Wiara i kultura, s. 152. 
Zagadnienie relacji wiary i kultury jest, szczególnie od Soboru Watykańskiego II, głęboką troską Kościoła. Jednym z najważniejszych dokumentów tego Soboru, ukończonym w grudniu 1965 roku, w ostatniej fazie prac soborowych, po długich dyskusjach i konsultacjach, jest Konstytucja Duszpasterska o Kościele w świecie współczesnym Gaudium et spes. Trzeba zaznaczyć, że Karol Wojtyła był jednym z bardziej aktywnych uczestników prac nad tym dokumentem. W kontekście przedstawianych tu rozważań na szczególną uwagę zasługuje rozdział tej Konstytucji poświęcony rozwojowi kultury (i tym samym relacji Kościoła z kulturą współczesną) oraz zadaniom chrześcijan w rozwijaniu kultury. $\mathrm{W}$ tym miejscu potrzebne wydaje się zacytowanie przyjętej w tejże Konstytucji definicji kultury, według której:

mianem kultury w sensie ogólnym oznacza się wszystko, czym człowiek doskonali i rozwija wielorakie uzdolnienia swego ducha i ciała; stara się drogą poznania i pracy poddać sam świat pod swoją władzę; czyni bardziej ludzkim życie społeczne, tak w rodzinie, jak i w całej społeczności państwowej, przez postęp obyczajów i dążenia instytucji; wreszcie w dziełach swoich w ciągu wieków wyraża, przekazuje i zachowuje wielkie doświadczenia duchowe na to, aby służyły one postępowi wielu, a nawet całej ludzkości (KDK 53) ${ }^{13}$.

Zawarta w tym dokumencie chrześcijańska interpretacja kultury pokazuje, że jest to ujęcie łączące oba wyróżnione wcześniej stanowiska, ale wyraźnie akcentujące nadrzędność doskonalenia człowieczeństwa, nawet jeśli przebiega ono różnie, odpowiednio do różnych sposobów życia, tworzących wiele kultur. W dalszej części tegoż rozdziału jeszcze wyraźniej mówi się o stawianiu w centrum kultury doskonalenia (się) człowieka w pełnej jego materialno-duchowej integralności: „Trzeba, aby kultura ludzka tak się dziś rozwijała [...], by harmonijnie urabiała całą osobę ludzką i pomagała ludziom wypełniać te zadania, do których powołani są oni wszyscy, zwłaszcza zaś chrześcijanie zespoleni po bratersku w jednej rodzinie ludzkiej" (KDK 56). I dalej „Kościół przypomina wszystkim, że kulturę odnosić należy do pełnej doskonałości osoby ludzkiej, do dobra wspólnoty i całej społeczności ludzkiej. Dlatego należy tak kształtować ducha, aby rozwijała się zdolność podziwiania, wnikania w głąb kontemplacji i urabiania sobie sądu osobistego oraz zdolność kształcenia zmysłu religijnego, moralnego i społecznego"

13 Sobór Watykański II, Konstytucja duszpasterska o Kościele w świecie współczesnym Gaudium et spes, w: Sobór Watykański II. Konstytucje, dekrety, deklaracje, Poznań 1967 w tekście KDK z odnośnym numerem. 
(KDK 59). Już jako papież Jan Paweł II wielokrotnie podkreślał, że nauczanie soborowe związane $\mathrm{z}$ relacją wiary i kultury z takim trudem przenika do praktyki życia Kościoła i postaw współczesnych chrześcijan. Znamienne są słowa z początku pontyfikatu (z roku 1982) skierowane do przedstawicieli społeczności jednego z europejskich uniwersytetów:

Nie ma bowiem sprzeczności pomiędzy kulturą i wiarą, co stanowczo podkreślił Sobór Watykański II; przeciwnie, mogą one nawzajem wyjaśniać się i wzbogacać. Stąd płynie szczególna odpowiedzialność chrześcijańskich naukowców oraz katolickich szkół wyższych, odpowiedzialność za przyczynienie się do usunięcia poważnego zakłócenia równowagi pomiędzy ogólną kulturą a pogłębianiem wiary, które - jak się wydaje - często bywa zakończone przedwcześnie, co musi się odbijać na postępowaniu chrześcijan i ich obecności w świecie ${ }^{14}$.

Kultura, by była żywa i rozwijała się, wymaga wolności, ponieważ wolność jest atrybutem osoby ludzkiej. Co więc znaczy w świetle myślenia chrześcijańskiego wolne tworzenie kultury, która równocześnie byłaby kulturą pełną, prawdziwą, doskonalącą człowieka, społeczeństwo i świat? Ten trudny problem pokazany w świetle prac soborowych znajdujemy w wypowiedzi Karola Wojtyły z 1964 roku, w ramach konferencji zorganizowanej przez „Tygodnik Powszechny” i „Znak” w Krakowie.

Wojtyła mówił tam o roli chrześcijan w tworzeniu kultury, potrzebie ich aktywnej obecności w kulturze. W tym czasie intensywne prace nad Konstytucją Gaudium et spes jeszcze trwały, ale już zarysowywały się główne jej zręby. Zacytujmy Karola Wojtyłę:

Przede wszystkim więc każdy chrześcijanin jest wyznawcą swojej wiary. Wyznawać to znaczy dawać świadectwo prawdzie bożej, objawionej przez Chrystusa i w Chrystusie, oraz własnemu o tej prawdzie przekonaniu. „Wyznawstwo" nie określa jakiejś odrębnej dziedziny działań, ale szuka dla siebie miejsca we wszystkich dziedzinach. Pozostaje ono w najściślejszym związku z tworzeniem kultury w tym jej najgłębszym, „najwewnętrzniejszym” znaczeniu, gdzie dziełem kultury jest po prostu sam człowiek $^{15}$.

14 Tenże, Dobro kulturalne każdego człowieka jest wartościq dla innych. Przemówienie do przedstawicieli Katolickiego Uniwersytetu Portugalskiego, Lizbona, 14.05.1982, w: Wiara i kultura, s. 146.

${ }^{15}$ K. Wojtyła, Chrześcijanin a kultura: nauka o Kościele odsłania prawdę o człowieku, w: Odnowa Kościoła i świata. Refleksje soborowe, Rzym 2014, s. 159-160. 
Dalej Wojtyła wyjaśnia, że wyznawstwo przenikające tworzoną kulturę przenosi się na jej wytwory - dzieła kultury, które nabierają szczególnego charakteru. I tu znów warto zacytować Autora. „Nie chodzi tutaj tylko o obecność na zasadzie treści materialnej, ale o daleko jeszcze ważniejszą obecność na zasadzie stylu, czyli treści formalnej. Chodzi o jakąś chrześcijańską miarę samego tworzenia, która oczywiście dopuszcza niezliczoną ilość wariantów i indywidualności" ${ }^{16}$. Problem przekładania wiary na kulturę stanie się później jednym z ważniejszych wątków pontyfikatu Jana Pawła II. Papież w różnych gremiach tłumaczył, dlaczego tak ważne współcześnie jest niedopuszczenie do tego, by wiara i kultura oddaliły się od siebie zarówno w świadomości ludzi, jak i w ich życiu. Od początku swojego pontyfikatu wielokrotnie podkreślał istnienie chrześcijańskiej koncepcji kultury, opartej na osobowym i wspólnotowym wymiarze doskonalenia się człowieka. Wyjaśniał, że kultura, będąc wyrazem i potwierdzeniem człowieka, jest głęboko zakorzeniona w Ewangelii, z niej czerpie swój dynamizm, prawdę o człowieku, sensie i celu jego życia, o towarzyszącej mu miłości Boga. Człowiek tworzy siebie ,wewnętrznym wysiłkiem ducha: myśli, woli, serca. I równocześnie człowiek tworzy kulturę we wspólnocie z innymi. Kultura jest wyrazem międzyludzkiej komunikacji, współmyślenia i współdziałania ludzi. Powstaje ona na służbie wspólnego dobra - i staje się podstawowym dobrem ludzkich wspólnot"17.

Wiele lat później w swojej ostatniej książce Pamięć $i$ tożsamość Jan Paweł II jeszcze raz podnosi problem zakorzenienia ludzkiej kultury w wierze. Warto przyjrzeć się temu ujęciu, które pojawia się pod koniec pontyfikatu Jana Pawła II i jest wyrazem wieloletniej pracy myślowej Papieża nad kulturą, jej sensem i rolą. Znajdujemy tam między innymi myśl, że słowa Boga z Księgi Rodzaju „Czyńcie sobie ziemie poddaną” są „najpierwotniejszą i najbardziej kompletną definicją ludzkiej kultury. Czynić sobie ziemię poddaną to znaczy odkrywać i poznawać prawdę o własnym człowieczeństwie [...]. Tym samym Bóg zadał człowiekowi konkretną misję: realizować prawdę o sobie samym i o świecie"18. Ta prawda, prawda o człowieku jako osobie ludzkiej, istocie stworzonej na obraz i podobieństwo Boga, jest prawdą o bożym rysie człowieczeństwa, a więc i kultury. Człowieczeństwo jest

16 Tamże, s. 160.

17 Jan Paweł II, Przemówienie do młodzieży na Wzgórzu Lecha w Gnieźnie, 3.06.1979, w: Podręcznik Pokolenia JPII. Ojcowskie słowo do młodych świata, Polski i Lednicy, Poznań 2008, s. 723.

${ }^{18}$ Tenże, Pamięć i tożsamość. Rozmowy na przełomie tysiqucleci, Kraków 2005, s. 85. 
bowiem „wszczepione w boskość Chrystusa”. I więcej: „Jedynie przyjmując zaszczepienie w boskości Chrystusa, człowiek może się w pełni zrealizować. Odrzucając to zaszczepienie, skazuje się w jakimś sensie na człowieczeństwo niepełne" 19 .

Zrozumienie, a przede wszystkim wprowadzanie w życie nauczania Chrystusa, przynależności i miłości do Niego, od początku nie było dla chrześcijan łatwe i nie mogło się oprzeć na żadnych gotowych wzorach zaczerpniętych z innych kultur. Wzory codziennego życia wiara, przykłady pomagające nadawać nowy kształt własnemu życiu, zmieniać je, tworzyć nową kulturę - kulturę chrześcijańską zostawił Chrystus w przypowieściach. Choć dzieją się w realiach Ziemi Świętej czasów Chrystusa, w sytuacjach zaczerpniętych z jej kultury, zawierają pouczenia ponadczasowe, stanowiące fundament kultury chrześcijańskiej. „Stając się człowiekiem, Syn Boży wniósł bowiem w dzieje ludzkości całe ewangeliczne bogactwo prawdy i dobra, a wraz z nim objawił także nowy wymiar piękna: orędzie ewangeliczne jest nim napełnione po brzegi" ${ }^{20}$.

Również biografie świętych wszystkich czasów i miejsc ukazują wielość i różnorodność sposobów życia, życia budowanego, począwszy od spraw zasadniczych do detali, na wierze, tym samym - tworzenia wewnętrznie zróżnicowanej, bogatej ale wyrastającej z jednej wiary w Chrystusa - kultury prawdziwej.

W tym kontekście zrozumiałe stają się słowa Jana Pawła II z jednego z przemówień do ludzi nauki, w których zwrócił uwagę, że dobro kulturalne - a więc wewnętrzna kultura jednego człowieka - jest wartością dla innych: „im większe jest czyjeś «dobro» kulturalne, tym bardziej musi ono być użyte - świadomie, czynnie, odpowiedzialnie i po chrześcijańsku - jako wartość «dla drugich»»"21. Ta myśl otwiera ważne perspektywy dla analizowania wychowawczych konsekwencji związków wiary i kultury. Jeśli wiara jest darem Boga, codzienne wierne praktykowanie wiary w każdej dziedzinie życia tworzy prawdziwą kulturę człowieka. Tym samym dar Boga dla osoby budującej swoje życie na wierze staje się, właśnie poprzez kulturę, darem Boga dla innych. Ważna jest więc świadomość, że człowiek kulturalny - uczciwy, uprzejmy, łagodny, pełen życzliwości i szacunku dla innych i świata, wrażliwy i uważny wobec innych - nie jest jedynie kimś, kto ma łatwe usposobienie, atrakcyjną osobowość, „kindersztubę”, ogólne obycie,

\footnotetext{
19 Tamże, s.103.

20 Tenże, List do Artystów, Watykan 1999, s. 12.

${ }^{21}$ Tenże, Dobro, s. 148.
} 
kogo spotkanie można traktować jak „los szczęścia”. Przeciwnie - każdy może być dla innych źródłem takiego pozytywnego doświadczenia kontaktu z kimś o kulturze prawdziwej. Podstawą jest nie samo ćwiczenie się w kulturze, ale wierne życie wiarą. Praktykowana wiara tworzy kulturę, a edukacja jako uczenie kultury jedynie pomaga szukać możliwie najlepszych form do wyrażania jej w życiu, motywuje do doskonalenia sposobu życia według kultury prawdziwej.

\section{Kultura wysoka owocem wiary i drogą do wiary}

Specjalna, niezastępowalną rolę w kulturze jako szukaniu i odkrywaniu prawdy o człowieku i świecie pełnią, wraz ze swymi odrębnymi drogami poznania, nauka i sztuka. Ważne miejsce zarówno w pontyfikacie dziś już świętego Jana Pawła II, jak i kontynuującego wysiłki na rzecz budowania związków wiary z kulturą Jego następcy, Benedykta XVI, zajmowały spotkania z przedstawicielami środowisk naukowych i twórczych. Ich omówienie wymagałoby odrębnego opracowania. Warto jednak przynajmniej zaznaczyć, że w czasie tych spotkań wyraźne było dążenie współczesnych następców św. Piotra do zbliżenia tych środowisk do Kościoła, uświadomienie im ich misji w świecie i znaczenia stałego dialogu z wiarą, wartości tego dialogu dla obu sfer życia człowieka - kultury (w tym przypadku nauki i sztuki) i wiary. W tekstach obu tych wybitnych papieży ostatnich lat stale powraca apel o obronę prawdy, docenienie oraz oddawanie sprawiedliwości wszystkim drogom poznania prawdy, w całej ich autonomii i specyfice zarówno poprzez wiarę, jak i na drodze poznania naukowego, wreszcie kontakt z pięknem. Najważniejsze, by wszystkim wybierającym daną drogę towarzyszyła świadomość istnienia jednej prawdy, do której wszyscy dążą, otwartość na wzajemne inspiracje, które mogą być wynikiem ich dialogu, odpowiedzialność za podejmowane działania i ich etyczny wymiar.

Nauka widziana przez pryzmat „kultury prawdziwej”, jeśli ma rzeczywiście wspierać rozwój człowieka i świata, musi zaakceptować ludzki wymiar kultury. W jednym z przemówień do ludzi nauki Jan Paweł II mówił:

Jako uczeni i badacze stanowicie międzynarodową wspólnotę, której działalność może być decydująca dla przyszłości ludzkości, ale pod warunkiem, że potraficie służyć prawdziwej kulturze człowieka i strzec tego cennego dziedzictwa. Waszym szlachetnym zadaniem jest praca nad rozwojem człowieka, nie tylko jego stanu posiadania, jego wiedzy czy siły. [...] To pojęcie kultury 
wynika z całościowego widzenia człowieka jako jedności ciała i duszy, osoby i wspólnoty, istoty rozumnej i uszlachetnionej przez miłośćc2.

Podobne oczekiwania kultura chrześcijańska stawia przed artystami. W Liście Jana Pawła II do artystów możemy przeczytać:

W rozległej panoramie kultury każdego narodu artyści mają swoje miejsce. Gdy idąc za głosem natchnienia, tworzą dzieła naprawdę wartościowe i piękne, nie tylko wzbogacają dziedzictwo kulturowe każdego narodu i całej ludzkości, ale pełnią także cenną posługę społeczną na rzecz dobra wspólnego. Odrębne powołanie każdego artysty określa pole jego służby, a zarazem wskazuje zadania, które go czekaja, ciężką pracę, do której musi być przygotowany, i wreszcie odpowiedzialność, którą winien podjąć. [...] Istnieje zatem pewna etyka czy wręcz „duchowość” służby artystycznej, która ma swój udział w życiu i odrodzeniu każdego narodu ${ }^{23}$.

W dalszym fragmencie tego tekstu powraca myśl, że kultura będąca owocem wiary, także więc sztuka, nie musi ograniczać się do jednoznacznych nawiązań religijnych. O jej zakorzenieniu w wierze decyduje jej rzetelność w dążeniu do prawdy, jej stosunek do człowieka i świata widzianych szerzej niż w ramach materialnego bytu i pragmatycznego przetrwania. Czytamy tam:

Sztuka bowiem, jeżeli jest autentyczna, choć niekoniecznie wyraża się w formach typowo religijnych, zachowuje więź wewnętrznego pokrewieństwa ze światem wiary, tak że nawet w sytuacji głębokiego rozłamu między kulturą a Kościołem właśnie sztuka pozostaje swego rodzaju pomostem prowadzącym do doświadczenia religijnego. Jako poszukiwanie prawdy, owoc wyobraźni wykraczającej poza codzienność, sztuka jest ze swej natury swoistym wezwaniem do otwarcia się na Tajemnicę ${ }^{24}$.

Kontakt ze sztuką jest nie tylko drogą odkrywania prawdy o człowieku, ale odkrywania Boga. Kultura jest tu drogą prowadzącą do wiary, ponieważ z niej wyrasta. Nie trzeba przypominać miłości św. Jana Pawła II do poezji, literatury, teatru, wrażliwości, z jaką mówił o wielkich dziełach malarstwa, ale także miłości Benedykta XVI do muzyki, wielu wypowiedzi i teksów,

\footnotetext{
22 Tenże, Przemówienie na Uniwersytecie, s. 310.

23 Tenże, List do Artystów, s. 10.

${ }^{24}$ Tamże, s. 26.
} 
w których papież Benedykt uświadamiał, jak ważną drogą do Boga jest droga przez piękno, jak niezwykłym wymiarem stworzonego przez Boga świata jest piękno, i jak ważnym elementem życia Kościoła jest troska o nie, dbanie o piękno liturgii. Najwyższe osiagnięcia ducha ludzkiego - kultura wysoka obejmująca dzieła i działania najwybitniejsze, ponadprzeciętne, wyjątkowe w odkrywaniu prawdy o świecie i ludziach, o ich doświadczaniu i przeżywaniu życia - budzą w człowieku potrzebę prawdy, tęsknotę za pięknem, gotowość do czynienia dobra, wrażliwość na transcendencję. Tym samym otwierają na łaskę wiary. Historia kultury pokazuje, że ogromna liczba tych wielkich dzieł wyrosła na gruncie wiary, stała się efektem głębokiego przeżycia wiary, świadectwem bogactwa dróg poszukiwania Boga i odnajdywania go przez ludzi różnych czasów.

Świat dzieł kultury artystycznej, przekazując przeżycia poszczególnych ludzi, społeczeństw czy narodów, jest ważnym budulcem i spoiwem ich pamięci i tożsamości, pomocą w rozumieniu siebie i swojej wspólnoty, czynnikiem wzmacniającym lub osłabiającym sens wysiłku doskonalenia siebie i swojego świata. Tekst książki Pamięć i tożsamość stanowi poruszające rozważanie i świadectwo widzenia w kulturze narodu - tu polskiego - owocu wiary chrześcijańskiej wielu jego pokoleń.

\section{4. „Kultura prawdziwa" - centrum wychowania i podstawa kultury szkoły}

Jednym z głównych środowisk kulturotwórczych jest szkoła jako miejsce edukacji formalnej, instytucja kształcąca i wychowująca. Ale jest też szkoła środowiskiem, w którym młode pokolenie spędza ogromną część swojego życia, część niezwykle ważną dla jego rozwoju. Szkoła odgrywa więc szczególną rolę w kształtowaniu się człowieka, a tym samym - w kształtowaniu się kultury.

Każda szkoła jest elementem szerszej kultury społeczeństwa i narodu, wprowadza w kulturę i ją buduje, pomaga w niej konstruktywnie uczestniczyć i twórczo się rozwijać. Równocześnie jako społeczność ma swoją wewnętrzną kulturę - swoją historię, tradycję, obrzędowość, symbolikę, swoje wartości, wzory, normy zarówno formalnie deklarowane i zapisane, jak i nieformalnie funkcjonujące, typowe zachowania członków społeczności szkolnej, język i sposoby porozumiewania się, sposoby rozwiązywania problemów, styl działania i atmosferę. Kultura ta oddziałuje na samo środowisko danej szkoły, ale i szerzej, na zewnątrz, przez naturalne interak- 
cje społeczne i programowe działania na rzecz innych. Szkoła jest wreszcie jednym $\mathrm{z}$ głównych środowisk, które powinno wspierać rodzinę $\mathrm{w}$ dziele wychowania.

W świetle chrześcijańskiej koncepcji kultury wychowanie oznacza proces sytuujący się w samym centrum kultury, jako przestrzeń doskonalenia się człowieczeństwa. Z tej perspektywy każda szkoła, będąc instytucją kształcącą i wychowująca, stymulującą i wspierającą rozwój uczniów, powinna starać się przynajmniej przeciwdziałać powstawaniu kultury „rozdartej”, rozwijaniu się kultury egoizmów jednostkowych i grupowych. Przeciwnie, wszelkimi sposobami powinna pracować na rzecz kultury „prawdziwej”.

Oczywisty kierunek szukania odpowiedzi kojarzy się w pierwszym rzędzie ze wzmocnieniem funkcji wychowawczej szkoły, przy założeniu stałej troski o poziom realizowanego w niej kształcenia. W wielu dokumentach Kościoła, a także w nauczaniu papieży i ich wypowiedziach do różnych gremiów, powraca wielokrotnie problem groźnego dla dzisiejszej kultury zdominowania szkolnictwa przez wąsko rozumiane kształcenie. Niestety coraz bardziej aktualna wydaje się diagnoza Jana Pawła II, wyrażona już w 1979 roku w słowach: „Myślę, że coraz bardziej w świecie współczesnym, w różnych tego świata systemach, wytworzonych na gruncie różnych ideologii, które zresztą mają dość wspólny korzeń, coraz bardziej będzie oczywiste, że sama tylko produkcja wykształconych, wysoko wyszkolonych, wyspecjalizowanych jednostek nie rozwiązuje [...] zagadnienia człowieka"25. Ten niepokój wybrzmiał jeszcze mocniej w cytowanym wcześniej przemówieniu w UNESCO w 1980 roku.

Kształcenie stanowiące i tworzące prawdziwą, pełną kulturę musi więc wyposażać uczniów w kompetencje, które nie ograniczają się do instrumentów skutecznego zdobywania i „posiadania” wiedzy i sprawności przydatnych na rynku pracy i w codziennym funkcjonowaniu instytucjonalno-społecznym. Do rozwijania człowieczeństwa potrzebne są kompetencje szersze, które pozwalają przygotowywać się do tego, żeby bardziej „być” - rozumieć świat, dokonywać $\mathrm{w}$ nim wyborów zgodnych z uznawanymi wartościami, podejmować wysiłek poznawania prawdy, kontemplowania piękna, realizacji dobra przez stawanie się dobrym dla innych i budowania dobra wspólnego, a na tej drodze - budowania dobra w sobie.

Tu mieszczą się także działania zmierzające do takiego przygotowania młodego człowieka do wejścia w kulturę, by mógł on zrozumieć kulturę

${ }_{25}$ Tenże, Przemówienie do profesorów i studentów Katolickiego Uniwersytetu Lubelskiego, 6.06.1979, w: Podręcznik, s. 731. 
własną, znalazł w niej swoje miejsce, docenił rolę tożsamości kulturowej w swoim życiu, życiu swoich bliskich, swojej społeczności i narodu, by chciał aktywnie bronić najważniejszych jej wartości. Przygotowywanie do tego, by człowiek mógł i chciał coraz bardziej świadomie pracować nad tym, żeby bardziej „być”, pracować nad sobą, nad swoim człowieczeństwem, jest istotą wychowania. To ono jest procesem prowadzenia, a potem wspierania i towarzyszenia w drodze do wartości, kształcenia charakteru, budowania pozytywnych postaw, postaw cechujących chrześcijanina.

Kształtowanie kultury, która miałaby być prawdziwym owocem wiary, musiałoby się rozpoczać od wiary. Zasadniczym krokiem w tym kierunku powinno być głębokie zrozumienie, przyjęcie i wprowadzanie w życie przez chrześcijan, sensu „bycia chrześcijaninem”.

Widzenie w kulturze owocu wiary, ale i świadome budowanie kultury w sobie i w świecie na fundamencie wiary, wymaga rzetelnej, wytrwałej pracy edukacyjnej oraz formacyjnej, która poszerzałaby w jednostkach i społeczeństwach świadomość istoty tego procesu - realizowania prawdy o człowieku i świecie w miłości.

\section{John Paul II - His Way of Thinking about the Connections between Faith and Culture - a Challenge for Christian Education (Summary)}

The author formulated a thesis that one of the biggest challenges for contemporary education, especially in a Christian form, is to convince the participants of educational process about the meaning and essence of introducing the relationship between faith and culture to life. Understanding of this relationship results from the adopted interpretation of "faith" and "culture". The dissertation presented an interpretation of John Paul's II tuition. The understanding of it demands mainly the comprehension of the concept of "genuine culture", which was introduced by John Paul II. It describes the way of life of a person who improves his or her humanity on the basis of truth and love. Such way of life is settled in faith. Art and science are special fields of life, which are dedicated to humanity, its improvement and understanding through searching for the truth and beauty. The author analyzed texts and speeches of John Paul II to reconstruct the sense of relationship between the genuine culture and faith, which they present. In the last part, she considered tasks of contemporary education, especially school one, in preparations for making the relationship between culture and faith come to life. 
Keywords: culture, genuine culture, relationship between faith and culture, culture of school, Christian education

\section{Jana Pawła II myślenie o związkach wiary i kultury - wyzwaniem dla wychowania chrześcijańskiego (Streszczenie)}

Autorka stawia tezę, że jednym z najważniejszych wyzwań dla współczesnego wychowania, szczególnie wychowania chrześcijańskiego, jest uświadomienie uczestnikom procesów wychowawczych sensu i znaczenia wprowadzania w życie relacji wiary i kultury. Rozumienie tej relacji wynika z przyjmowanej interpretacji „wiary” i ,kultury”. W tekście przedstawiona jest interpretacja zawarta w nauczaniu Jana Pawła II. Jej zrozumienie wymaga przede wszystkim zrozumienia wprowadzonego przez Jana Pawła II pojęcia „kultury prawdziwej”. Oznacza ona sposób życia człowieka doskonalącego swoje człowieczeństwo na podstawie prawdy i miłości. Taki sposób życia zakorzeniony jest w wierze. Szczególnymi dziedzinami poświęconymi człowieczeństwu, jego poznawaniu i doskonaleniu przez dążenie do prawdy i piękna, są sztuka i nauka. Autorka analizuje teksty i wypowiedzi Jana Pawła II, żeby zrekonstruować przedstawiony w nich sens relacji kultury prawdziwej i wiary. W ostatnim fragmencie rozważa zadania współczesnego wychowania, szczególnie wychowania szkolnego, w przygotowywaniu do wprowadzenia w życie związków kultury i wiary.

Słowa kluczowe: kultura, kultura prawdziwa, związki wiary i kultury, kultura szkoły, wychowanie chrześcijańskie 